\title{
La constitución de la Argentina democrática en el discurso de asunción presidencial de Raúl Alfonsín*
}

\author{
María Alejandra Vitale** \\ Mariano Dagatti***
}

Recibido: 16 de septiembre de 2015

Evaluado: 15 de diciembre de 2015

Aceptado: 20 de enero de 2016

\section{Resumen}

Desde la perspectiva de la retórica constitutiva, este artículo estudia el discurso de asunción del presidente argentino Raúl Alfonsín ante el Congreso de la Nación (10 de diciembre de 1983). Con herramientas tomadas de la retórica y del análisis del discurso, se estudia cómo esta alocución constituye la democracia después de siete años de dictadura (1976-1983), performando un auditorio heterogéneo, compuesto por diferentes filiaciones políticas e ideológicas, en un sujeto democrático unido y plural, aglutinado en torno a una ética cívica.

Palabras clave: retórica constitutiva, discurso de asunción, Raúl Alfonsín, democracia, sujeto democrático.

\footnotetext{
Artículo de investigación. Este artículo fue elaborado en el marco del proyecto de colaboración entre Argentina y la República de Sudáfrica titulado Discursos fundacionales e identidades nacionales en Argentina y Sudáfrica, dirigido por la Dra. María Alejandra Vitale y el Dr. Philippe-Joseph Salazar y susbsidiado por el Ministerio de Ciencia, Tecnología e Innovación Productiva y la National Research Foundation. El proyecto se propone identificar y analizar discursos públicos que han sido fundacionales o constitutivos en los procesos de construcción de la nación argentina y la sudafricana. Cómo citar este artículo: Vitale, M.A. y Dagatti, M. (2016). La constitución de la Argentina democrática en el discurso de asunción presidencial de Raúl Alfonsín. Hallazgos, 13(26), 65-91 (doi: http://dx.doi.org/10.15332/s1794-3841.2016.0026.03).

** Posdoctorado en Estudios Lingüísticos, de la Universidad Federal de Minas Gerais(Brasil). Profesora Titular en la Universidad de Buenos Aires. Correo electrónico: vitaleale@fibertel.com.ar. Sánchez de Bustamante 24685 B, CABA (1425), Argentina.

*** Doctor en Letras con orientación Lingüística, de la Universidad de Buenos Aires. Profesor asistente en la Universidad de Buenos Aires, investigador en la Universidad Nacional de Quilmes y becario posdoctoral del ConIcet.Correo electrónico: mjdagat@yahoo.com.ar. Jorge Newbery 2831 PB 2 , CABA, Argentina.
} 


\title{
The constitution of democratic Argentina in Raúl Alfonsín's inaugural address
}

\begin{abstract}
From the standpoint of constitutive Rhetoric, this paper elaborates on Argentine president RaúlAlfonsín's inaugural address in Congress (December 10th, 1983). Methodological tools from Rhetoric and Discourse Analysis work together in order to explain how this speech constitutes democracy after seven years of dictatorship (1976-1983), while performing a heterogeneous audience composed by different political and ideological positions into a plural and united democratic subject, bound together by civic ethics.
\end{abstract} Received: September 16, 2015 Evaluated: December 15, 2015 Accepted: January 20, 2016

Keywords: Constitutive Rhetoric, inaugural address, Raúl Alfonsín, democracy, democratic subject. 


\title{
A constituição da Argentina democrática no discurso de posse presidencial de Raúl Alfonsín
}

\begin{abstract}
Resumo
Recebido: 16 de setembro de 2015

Desde a perspectiva da retórica constitutiva, este artigo estuda o

Avaliado: 15 de dezembro de 2015

Aceito: 20 de janeiro de 2016 discurso de posse do presidente argentino Raúl Alfonsín no congresso da Nação (10 de dezembro de 1983). Com ferramentas tomadas da retórica e da análise do discurso, estuda-se como esta alocução constitui a democracia depois de sete anos de ditatura (1976-1983), performando um auditório heterogêneo, composto por diferentes filiações políticas e ideológicas, em um sujeito democrático unido e plural, aglutinado em torno a uma ética cívica.

Palavras-chave: retórica constitutiva, discurso de posse, Raúl Alfonsín, democracia, sujeito democrático.
\end{abstract}




\section{INTRODUCCIÓN}

En el marco general de la retórica constitutiva (Anderson, 2007; Bruner, 2002; Charland, 1986), el objetivo de este artículo es indagar el carácter fundacional del discurso de asunción del ex presidente argentino Raúl Alfonsín, pronunciado el 10 de diciembre de 1983 ante el Congreso de la Nación (en adelante, DARA). El trabajo se inserta en una investigación de mayor alcance que tiene el propósito de identificar y caracterizar, en Argentina y Sudáfrica, un amplio conjunto de discursos clave que sirvan al estudio de los principios discursivos de dos sociedades políticas ubicadas en el Atlántico Sur.

La particularidad de este discurso radica en que constituye al pueblo argentino como sujeto democrático, en el contexto de retorno a la democracia después de la última dictadura militar (1976-1983). Esto es, que delinea el perfil de una nación democráticapor la vía de la retórica y performa un auditorio heterogéneo, compuesto por diversas filiaciones políticas e ideológicas, en un sujeto democrático unido, por cuanto lo aglutina en torno a una ética cívica. Resulta clave, en este sentido, puesto que orienta el comienzo de un nuevo periodo histórico del país y reconfigura la identidad de su audiencia en el marco de la democracia. Por estas razones, analizamos con herramientas de la retórica y el análisis del discurso, en primer lugar, el gesto fundacional del DARA, que postula, en la situación de posdictadura, a la democracia como solución integral de las múltiples demandas sociales. Este gesto involucra, asimismo, una dimensión pedagógica que apuesta a persuadir al pueblo de que la democracia puede ocuparse de demandas de todo tenor. La imbricación del pluralismo ideológico en un "sentimiento ético" que permite unificar al pueblo es una tercera faceta por considerar.

A continuación delinearemos, en primer lugar, la perspectiva de la retórica constitutiva como marco teórico general del trabajo; en segundo lugar, presentaremos los antecedentes de nuestra investigación en el ámbito de las ciencias sociales $\mathrm{y}$, de manera específica, en los estudios de discurso; por último, y con detalle, daremos cuenta de nuestro análisis y expondremos los principales resultados.

\section{LA RETÓRICA CONSTITUTIVA}

El poder performativo otorgado al lenguaje se remonta a la antigüedad. Manfred Kraus (2012) recuerda que en Gorgias los poderes del logos son comparados con las drogas medicinales, el encantamiento mágico o la fuerza física, lo que puede crear, eliminar o modificar las emociones en el alma humana, pero también afectar y manipular las opiniones atesoradas en ella.

La definición misma de retórica que brinda Aristóteles como la facultad de ver en cada caso los medios aptos para persuadir (Ret. 1, 1 1355b) manifiesta que el efecto buscado en los destinatarios es en ella sustancial. En relación con esto, Antonio López Eire (2002, 2005a y 2005b) hizo hincapié en que los griegos pensaron la retoricidad del lenguaje como capacidad pragmática, es decir, para hacer cosas en el ámbito político-social e influir en los ciudadanos mediante argumentos más bien psicológicos que lógicos. El carácter retórico del lenguaje lo vuelve así instrumento pragmático, útil para actuar en el mundo y sobre los otros. 
La concepción pragmática del lenguaje que está en la base de la definición de Retórica que remite a la persuasión como efecto en el oyente fue asumida de modo radical por los sofistas, dado que, como plantea Barbara Cassin (2008), el efecto retórico sobre el comportamiento del oyente es para los sofistas solo una parte de lo que ella llama "efecto mundo". Se trata de la concepción del discurso como productor del mundo, como engendrador del ser; en suma, el discurso hace ser. Por ello Cassin (2008) remite al título del libro de Austin (2003) Cómo hacer cosas con palabras y afirma: "el discurso sofístico no es solo una performance en el sentido epidíctico del término, sino un performativo con todas las de la ley, en el sentido austiniano; es demiúrgico, fabrica el mundo, lo hace acaecer" (p. 72).

Laurent Pernot (2013, p. 113), por su parte, destacó también el valor performativo de la palabra en el mundo romano, en el sentido de que "es por sí misma una acción que produce eficacia y produce una situación nueva; sirve para dar órdenes, para prometer, enunciar reglas" $y$, mal empleada, puede provocar resultados funestos. De allí que la comunicación, especialmente la efectuada en el ámbito público, fuese controlada y sometida a las jerarquías.

Este valor del poder performativo de la palabra es recuperado en los tiempos actuales por la corriente de los estudios retóricos que se conoce como retórica constitutiva. El término retórica constitutiva fue acuñado por James Boyd White (1985) con referencia a la capacidad del lenguaje para crear la identidad colectiva de una audiencia. El término fue retomado y difundido por el académico canadiense Maurice Charland (1986), quien focaliza la noción de identificación ${ }^{1}$ como término clave para la retórica. La noción de identificación permite repensar el efecto retórico a la vez que rechaza la idea de un sujeto trascendental que ocuparía el lugar de la audiencia, que existiría antes, de modo independiente del discurso. La idea central de la retórica constitutiva según Charland es que las audiencias existen por el discurso, en el sentido en que este las construye, lo que implica examinar como efecto retórico lo que Louis Althusser ubica como el proceso clave de la ideología: la constitución de un sujeto.

Volviendo a la afirmación de Aristóteles, que retoma la de Sócrates, de que no es difícil alabar a los atenienses delante de los atenienses (Ret. 1, $91367 \mathrm{~b}$ ), la retórica constitutiva se pregunta más bien cómo estos llegan a la experiencia de ser atenienses. Charland analiza así la construcción retórica del pueblo quebequense. Recuerda que en 1967, el año del Centenario de Canadá, se formó en Quebec una nueva asociación política, el Mouvement Souveranité Association (MSA), que en francés-la lengua mayoritaria de Quebec-, llamó a la independencia de Quebec de Canadá y declaró: “Noussommes des Québécois". Hasta el momento, los habitantes de Quebec se habían llamado "Canadiens français", por ello Charland interpreta que aquella fue una instancia fundamental de la retórica constitutiva del pueblo quebequense, que dio existencia a un nuevo sujeto político. La existencia de este sujeto político, con su identidad nacional, sería presentada como justificación para la creación de un nuevo Estado.

1 Charland retoma a Kenneth Burke (1967) para sustituir la noción de persuasión por la de identificación como esencial en la retórica. 
Michael Bruner (2002), por su parte, focaliza la dimensión retórica de la construcción de la identidad nacional en momentos específicos en los que articulaciones narrativas en competencia colisionan en el proceso de negociación discursiva sobre qué significa ser parte de una nación determinada. ${ }^{2}$ Destaca así que la dimensión retórica de las identidades nacionales es políticamente significativa porque los diferentes tipos de identidades colectivas conducen a diferentes formas de comunidad, a diferentes tipos de relaciones locales e internacionales. En el marco de su reflexión sobre el papel central de las narrativas y de la memoria pública en la construcción retórica de las identidades, Bruner sostiene que los líderes públicos apelan a la historia monumental ${ }^{3}$ para crear apoyos masivos a sus políticas y obtener legitimidad para llevar a cabo ciertas acciones. Asimismo, considera que intentan fabricar una base común sobre qué es "el pueblo", que pueda movilizar a la ciudadanía, especialmente en tiempos de crisis.

Dana Anderson (2007) es otra autora que se inscribe en la corriente de la retórica constitutiva. Destaca que esta corriente ha focalizado el modo como los oradores construyen la identidad de su audiencia, y en este sentido operan una "conversión" retórica de dicha identidad, pero que ella, en cambio, considerará cómo los oradores construyen

2 Explora los casos de Alemania Occidental en 1988, de Rusia en 1993 y de Canadá en 1995

3 Bruner retoma los tres tipos de historia distinguidos por F. Nietzsche: la historia monumental, anticuaria y crítica. La historia monumental construye un pasado digno de ser imitado que se usa como un incentivo para la acción en el presente; la historia anticuaria consta de un registro puramente cronológico, pero aún es profundamente selectiva a causa de que es imposible registrar cada detalle relevante de un acontecimiento histórico. La historia crítica, finalmente, se enfrenta a las historias monumentales y anticuarias con el objetivo de señalar injusticias sobre qué omiten y cómo realizan las omisiones. sus propias identidades a través de una "conversión" que se oriente a persuadir a la audiencia. La tensión identificación/división es central para lo que Anderson llama dialéctica constitutiva.

\section{Antecedentes: EL ALFONSINISMO EN LAS CIENCIAS SOCIALES Y EL ANÁLISIS DEL DISCURSO}

El 10 de diciembre de 1983, Raúl Alfonsín asume la presidencia de la República Argentina después de siete años de dictadura militar. Cuarenta días antes había sido electo en las urnas con casi el $52 \%$ de los votos, en una elección comparable a las victorias plebiscitarias de Juan Domingo Perón o Hipólito Yrigoy en, líderes históricos, respectivamente, del Partido Justicialista y de la Unión Cívica Radical. ${ }^{4}$

El Gobierno de Alfonsín fue parte - señala Wando Ansaldi-de un proceso subregional de transición de dictaduras institucionales de las Fuerzas Armadas a regímenes políticos democráticos (citado en Pucciare1li, 2006, p. 23). En Argentina, el autodenominado "Proceso de Reorganización Nacional" había impuesto un régimen represivo con un saldo de miles de muertes, torturas y "desapariciones". A la herencia del terror se le sumó una crisis económica signada por la inflación y el crecimiento de la deuda externa.

4 En el escenario del saldo destructivo que la dictadura militar dejó a la democracia - su mayor y dramático exponente fueron las víctimas del Terrorismo de Estado-, Alfonsín, líder renovador de la Unión Cívica Radical, le ganó las elecciones presidenciales al candidato del peronismo, Italo Luder, por una diferencia de casi el $12 \%$. Empero, el peronismo ganó en la mayoría de las provincias por lo que tuvo preeminencia en el Senado y debilitó el predominio radical en la Cámara de Diputados. 
Como plantean Novaro y Palermo (2003), la derrota argentina en la Guerra de Malvinas significó el colapso del régimen militar en ausencia de un poder civil movilizado y estructurado, aunque influyó decisivamente en que las fuerzas políticas reunidas en la Multipartidaria $^{5}$ desarrollaran una estrategia de presión moderada respecto de las condiciones y tiempos de una salida electoral, fijada finalmente para la segunda mitad de 1983. " "A fines de 1982, difícilmente otra país del mundo presentaba una situación más alarmante y desdichada" (p. 19). Esta frase de David Rock (1991) en su libro Argentina 1516-1987, aunque no carece del pathos de la hipérbole, describe de forma concisa la crisis política, social y económica de Argentina heredada del Gobierno militar.

Interesadas por los avatares de la posdictadura y por el papel de la política en la denominada "transición democrática", las ciencias sociales han manifestado un continuo interés por el alfonsinismo. En el dominio de las ciencias políticas, la sociología y la historia, es menester señalar los estudios pioneros de Aznar et al. (1986), Nun y Portantiero (1987) y De Riz (1989). La herencia social, política y económica de la última dictadura y las dificultades del alfonsinismo para consolidar su hegemonía política enmarcan las hipótesis de trabajo de Epstein (1992), Delamata (1997), Aboy Carlés

5 Integrada por el Partido Radical, el Partido Justicialista, el Movimiento de Integración y Desarrollo, la Democracia Cristiana y el Partido Intransigente, la Multipartidaria se formó el 14 de julio de 1981 como espacio para alentar y negociar la política de apertura que supuestamente intentaba desenvolver el presidente militar del momento, el general Roberto E. Viola.

6 Respecto a los consensos y conflictos políticos de la transición, véase Velázquez Ramírez (2015). El autor plantea una visión parcialmente diferente del periodo, señalando la sobreestimación del caso Malvinas en el deterioro de la legitimidad del Gobierno militar y la paralela subestimación del "espacio político partidario".
(2001) y Barros (2002). Como parte de sus investigaciones sobre la Argentina contemporánea, Novaro $(2006,2010)$ ha indagado el Gobierno radical bajo la óptica de las relaciones entre democracia, mercado y nación. Dos compilaciones recientes, Los años de Alfonsin (Pucciarelli, 2006) y Discutir Alfonsín (Gargarella, Murillo y Pecheny, 2010) ofrecen un panorama contemporáneo del periodo y el legado alfonsinista.

En el ámbito de los estudios de discurso, los trabajos de investigación del equipo dirigido por Beatriz Lavandera, publicados en los Cuadernos del Instituto de Lingüística de la Universidad de Buenos Aires (1986, 1987), constituyen una referencia insoslayable. Integrantes de ese grupo propusieron luego en forma individual análisis sobre series discursivas o actos políticos específicos del líder radical: por ejemplo, Menéndez y Raiter (1986), García Negroni (1988), Zoppi Fontana (1993, 1995). El artículo de Leonor Arfuch (1987) sobre la competencia electoral de 1983 entre peronistas y radicales resulta una referencia de peso a la hora de considerar la matriz ideológica del futuro Gobierno. Política, medios y discurso en la Argentina, compilado por Podetti, Qués y Sagol (1992), también resulta una referencia para pensar la cuestión del alfonsinismo.

Ciudadanos modernos (1997), la tesis doctoral de Zoppi Fontana, constituye el primer abordaje sistemático del discurso alfonsinista: en esa obra la autora indaga la temática de la modernización en las alocuciones del líder radical y, en la línea de la Escuela Francesa de Análisis del Discurso, estudia el significado de la democracia como punto nodal del poder de transformación de su palabra pública. Los trabajos de Oscar Landi 
(1985) yAlejandro Raiter (1999) también presentan aportes relevantes: Landi expone las principales líneas de la palabra de Alfonsín $\mathrm{y}$, en términos más generales, las orientaciones dominantes de la cultura política de la transición democrática, mientras que Raiter aborda diferentes aspectos del discurso de Alfonsín, sobre todo ciertas "transformaciones discursivas" ${ }^{7}$ que definen en el caso de estudio el pasaje de una orientación socialdemócrata a una orientación neoliberal.

El aporte de este artículo respecto al estado del arte consiste en indagar el DARA, a partir del marco teórico-metodológico de la retórica constitutiva, como una instancia decisiva de convergencia entre el acontecimiento discursivo institucional y la estructura política, social y cultural de la transición. Los estudios relevados han destacado, por ejemplo, que el Gobierno de Alfonsín había tenido al principio la iniciativa discursiva (Raiter, 1987) y que, en relación con ello, su Gobierno "aparecía situado [según Gargarella] 'por delante' de una sociedad 'rezagada' luego de años de conservadurismo atroz y de diverso signo y procuraba instalar en la sociedad, 'desde arriba', nuevos temas relacionados con la recuperación de derechos, esperando la aquiescencia social posterior" (Gargarella, Murillo y Pecheny, 2010, p. 31). En la misma dirección, se ha señalado el ánimo "regenerativo" del alfonsinismo que tenía, por un lado, el objetivo de establecer una frontera con el pasado reciente $y$, por

7 Entendida como "operación realizada en un discurso o conjunto de discursos para definir una realidad discursiva diferente a la existente en el momento de la enunciación", el uso de la noción de transformación discursiva para analizar el discurso alfonsinista constituye un antecedente de relevancia a la hora de abordar el DARA desde la retórica constitutiva, ya que el objetivo de esta operación es "lograr un cambio de conductas, creencias y actitudes en los destinatarios" (Raiter, 1999, p. 97). el otro, el de apostar a una reconciliación de los actores por vía de un pacto constitucional y normativo (p. e. Aboy Carlés, 2001; Novaro, 2010). Sin embargo, ninguno de los trabajos relevados concentra su atención en el estudio específico del discurso inaugural, pese a que se trata del primero presidencial que, de acuerdo con Gabriel Vommaro, apela a la democracia no solo como la forma más legítima de resolución de problemas y conflictos, sino como valor en sí mismo. El alfonsinista representa, para el autor, un discurso "en cierta forma inédito en la tradición política argentina, en la que se rechazaba de diversas maneras la formalidad democrática en nombre de otros principios trascendentes como la justicia social, el socialismo, el orden o la modernización" (citado en Pucciarelli, 2006, p. 262).

Más aún, el peso de la palabra en los inicios del Gobierno de Alfonsín era tal que, como estiman varios autores, no es exagerado afirmar que el alfonsinismo queda preso en la propia operación discursiva desplegada durante la campaña (Cavarozzi, 1997), ya que de manera casi inmediata "se pondrá en evidencia que el optimismo había resultado exagerado frente al formidable conjunto de problemas estructurales que se presentaron en el corto plazo" (Schvarzer, 1998, p. 176). Claudia Hilb (1990) habla, en esta línea, de un "exceso de predicación", es decir, en "un repertorio de promesas que recogen las aspiraciones postergadas de la gente" sin considerar "el estado de la relación de fuerzas existentes entre las distintas formas de poder en disputa", ni las "estrategias institucionales para superar el conjunto de obstáculos estructurales generados durante el período dictatorial" (p. 14). De manera sugerente, Catalina Smulovitz titula 
su presentación en Discutir Alfonsín "La ilusión del momento fundante", en la cual afirma: “El 'entusiasmo democrático' de 1983 no sólo nos permitió creer que podríamos domesticar los problemas de la Argentina, sino también que el orden político podía recrearse desde la nada" (citada en Gargare1la, Murillo y Pecheny, 2010, p. 9).

Por lo tanto, a pesar de que la democracia se vuelve, por decirlo en los términos de Kraus (2014), un "culture-sensitive argument", y de que la dimensión simbólica del alfonsinismo es invariablemente destacada, calificada como fundante en lo que respecta a la situación argentina, el DARA no ha sido analizado de manera exhaustiva como discurso constitutivo de la democracia naciente y como pieza fundamental de las operaciones simbólicas del nuevo proceso político. En los próximos apartados se consideran las características retóricas del gesto fundacional, se justifica en el plano discursivo el carácter "ampliado" de la democracia y se destaca, en el marco de la apuesta ética del radicalismo, la crítica incisiva a las minorías, sean de izquierda o derecha, opuestas al gobierno de las mayorías, que ofrece pistas de la disposición del alfonsinismo a la conformación de un "tercer movimiento histórico". Por último, se describe cómo el DARA realiza la "conversión" retórica de una audiencia heterogénea en un pueblo unido en la pluralidad, debido a la inescindible relación que plantea entre democracia, pueblo y vida.

\section{LA CONSTITUCióN DE LA Argentina democrática}

Considerando la perspectiva de la retórica constitutiva y el estado del arte sobre el discurso alfonsinista, el objetivo específico de este artículo es indagar el carácter constitutivo del DARA. Surge la pregunta de cómo Alfonsín constituye la democracia por la vía de la retórica; o mejor dicho, cómo performa un auditorio heterogéneo, compuesto por diversas filiaciones políticas e ideológicas, en un sujeto democrático unido y plural, aglutinado por una ética cívica. La respuesta implica, en primer lugar, analizar el gesto fundacional del DARA, que postula a la democracia, en la situación de posdictadura, como solución integral de las múltiples demandas sociales. Este gesto involucra, en segundo lugar y en la definición de una pedagogía democrática, una dimensión ética, que intenta articular bajo un nuevo signo unión nacional y pluralismo ideológico.

Reconstruir la unidad nacional y crear un centro legítimo de autoridad por encima de las partes - aspectos ambos de un mismo proceso - son, según Liliana De Riz (1989), el dato crucial para analizar el desafío democrático planteado en 1983. En este contexto, Alfonsín decide pronunciar su discurso inaugural ante el pueblo argentino en una fecha y en un lugar particular. El 10 de diciembre se conmemora el Día Internacional de los Derechos Humanos y el presidente, cuyo discurso de campaña había contrastado con el discurso represivo dominante, elige esta fecha para iniciar un nuevo ciclo.

\section{El gesto fundacional}

El gesto fundacional ${ }^{8}$ del DARA puede ser inscripto en una larga serie de estrategias de gobierno que han intentado definir una frontera política entre un pasado reciente

\footnotetext{
8 El ánimo fundacional del discurso alfonsinista ha sido señalado por diferentes autores: entre otros, Zoppi Fontana (1993, 1997), Aboy Carlés (2001) y Barros (2002).
} 
repudiado, que se requiere aún visible y presente, y la construcción de un futuro auspicioso, que emerge como el anverso de ese orden injusto que ha de ser abandonado. Hipólito Yrigoy anteponía la causa radical a un régimen "falaz y descreído" que habría tenido sus orígenes en la presidencia decimonónica de Miguel Juárez Celman; el peronismo clásico confrontaba las desdichas de la "Década infame" con la instauración de una "nueva Argentina, justa, libre y soberana". "Nace la democracia y renacen los argentinos"; era el corolario de la fórmula con que Raúl Alfonsín, bajo el denominador común del rechazo al Gobierno dictatorial, aglutinaba las expectativas democráticas de sectores heterogéneos.

Sabemos que, en el plano discursivo, estas estrategias de ruptura apelan con frecuencia a la puesta en escena de un tópico fundacional (Charaudeau, 2009), que consiste en la representación esquemática de una situación juzgada desastrosa (y sus víctimas), una fuente del mal (y sus responsables) y una solución (y su garante). ${ }^{9}$ El DARA no constituye una excepción, y el siguiente fragmento lo sintetiza:

El país atraviesa un momento crucial de su historia nacional: la línea divisoria que separa una etapa de decadencia y disgregación de un porvenir de progreso y bienestar en el marco de la democracia. El restablecimiento del imperio de la ley debe redoblar nuestros

9 Véase, a este respecto, Charaudeau (2009), quien plantea la presencia de este tópico en el discurso populista y pone el acento en la autorepresentación del líder como garante de la solución anunciada. Se cree acá que la presencia del tópico excede a la cuestión del populismo y que, por lo tanto, puede hablarse de un tópico fundaciona en discursos políticos de variada índole. La única salvedad es que entendido en esta perspectiva más amplia, el líder puede no ser el único garante de la solución anunciada. esfuerzos para enfrentar creativamente los problemas del ahora. El desafío que tenemos por delante es grande; convertir la emergencia en la que nos encontramos en la oportunidad para reanimar las potencialidades de la sociedad, durante tanto tiempo sofocadas bajo el peso del autoritarismo. (Alfonsín, 1983, p. 10)

La enunciación presidencial, reglada por el género epidíctico, ${ }^{10}$ constituye el presente de la nación y la nación como presente: "El país atraviesa un momento crucial de su historia nacional", o bien "los problemas del ahora". Plantea, en ese marco, una "línea divisoria" que corta en dos la "historia nacional": "una etapa de decadencia y disgregación", la "emergencia en la que nos encontramos", y "un porvenir de progreso y bienestar en el marco de la democracia", que brinde la "oportunidad para reanimar las potencialidades de la sociedad, durante tanto tiempo sofocadas bajo el peso del autoritarismo". El uso de la primera persona del plural en forma inclusiva ("nuestros esfuerzos", "El desafío que tenemos por delante", la emergencia en la que nos encontramos") coloca al orador y a su auditorio en un presente de cara al futuro, y deja indeterminada la relación del colectivo con el pasado. La situación liminar, "la línea divisoria", delinea, asimismo, la disyunción centra la partir de la oposición entre la "democracia" y el "autoritarismo": la primera como condición sine qua non del porvenir ("marco": figura de encuadre, amplitud y espacio); el segundo como signo del pasado de opresión ("peso", "sofocadas").

\footnotetext{
10 Dentro del discurso político, Campbell y Jamieson (2008) consideran el género discurso de asunción como un subtipo de discurso epidíctico porque afirma valores que unen al pueblo y evita la polémica.
} 
La representación de esta situación de "emergencia" o de "decadencia y disgregración" combina en el DARA una retórica de la acumulación con procedimientos evidenciales. ${ }^{11}$ El siguiente párrafo es, al respecto, significativo:

El estado en que las autoridades nacionales reciben el país deplorable y, en algunos aspectos, catastrófico, con la economía desarticulada y deformada, con vastos sectores de la población acosados por las más duras manifestaciones del empobrecimiento, con situaciones sociales que reflejan crudamente el impacto de la miseria, con un endeudamiento de insólito volumen y de origen muchas veces inexplicable, que compromete gran parte de los recursos nacionales para un largo futuro, con una inflación desbordada cuyos efectos son una verdadera afrenta para los hombres que producen y trabajan, con un clima de arbitrariedad, atropello e incertidumbre creado por la absurda pretensión de gobernar por el miedo y la prepotencia, con la cultura postergada y perseguida en muchas de sus expresiones, con la educación y la salud relegadas a un segundo plano y consiguientemente convertidas en privilegio de los menos, con una situación internacional agravada por decisiones irresponsables cuyas consecuencias se transfirieron imprudentemente a un futuro y que ahora vienen a depositarse en nuestras

11 La evidencialidad es una categoría semántica relacionada con la modalidad epistémica. Como afirman García Negroni y Tordesillas (2001), "si las nociones epistémicas son relativas a las creencias (i.e. al saber) del hablante, la evidencialidad se relaciona con los distintos modos en que el locutor ha obtenido el conocimiento en cuestión: el locutor lo sabe de oídas, ha sido testigo presencial, lo deduce por inferencia a partir de ciertos indicios, se la han contado, etc." (p. 110). manos; con la carga afligente de todos esos males, cuya cuenta precisa y detallada puede ser excusada aquí por ser bien conocida, tendremos que enfrentarnos, a partir de hoy, no sólo a la tarea de corregirlos y eliminarlos para siempre, sino a la de echar los cimientos de la Argentina libre, grande, próspera, fraterna y generosa que queremos. $Y$ lo hacemos, desde luego, juntos y unidos en esa decisión reparadora que todos compartimos. (Alfonsín, 1983, p. 5)

La descripción del "país deplorable" y "catastrófico" que realiza el DARA apuesta a una enumeración acumulativa de fenómenos calificados de manera disfórica-sin agentes responsables determinados - que disuelve las causas y los efectos en un ethos autoritario de época: "un clima de arbitrariedad, atropello e incertidumbre creado por la absurda pretensión de gobernar por el miedo y la prepotencia" (Alfonsín, 1983, p. 5). La indeterminación de los responsables encuentra en las nominalizaciones ("las más duras manifestaciones del empobrecimiento", "el impacto de la miseria", "endeudamiento", "la absurda pretensión de gobernar") y en los participios calificativos ("una economía desarticulada y deformada", "vastos sectores de la población acosados", "una inflación desbordada", "la cultura postergada y perseguida", "la educación y la salud relegadas..., convertidas en privilegio", "una situación internacional agravada") formas de mitigación que refuerzan su carácter impersonal, poniendo el acento en una situación, en un estado, antes que en los efectos de las prácticas de un conjunto de actores definidos.

Enumeración acumulativa e indeterminación dejan entrever una característica nuclear del gesto fundacional del DARA: los responsables 
del "país deplorable" no aparecen nombrados de modo explícito a causa del uso de recursos que Beatriz Lavandera (1986) denomina "mitigadores de la aserción". Estos recursos regulan el carácter explícito de lo dicho y permiten expresarse vagamente, para decir y dejar entender lo que no se dijo. De esta manera, en la alocución de Alfonsín se destacan las nominalizaciones verbales con elisión del complemento preposional agente, como "el quebrantamiento de los derechos del pueblo" (Alfonsín, 1983, p. 4) ${ }^{12}$ y "el estéril tutelaje sobre los habitantes de este país" (Alfonsín, 1983, p. 6); la forma impersonal se, por ejemplo: "se impide al pueblo decidir su propia suerte" (Alfonsín, 1983, p. 48), y la elección para la función de agente de nominalizaciones abstractas que designan cualidades de los agentes, que quedan aludidos pero no nombrados, como en "hay fuerzas poderosas que no quieren la democracia en Argentina" (Alfonsín, 1983, p. 48).

Confluyen estas estrategias de mitigación e indeterminación con procedimientos evidenciales que garantizan, desde la apelación a un saber colectivo, un acuerdo universal sobre "la grave situación del país" (Alfonsín, 1983, p. 25) que el nuevo Gobierno debe enfrentar: "Esas dificultades son múltiples e inmensas, bien lo sabemos, pero vamos a salir adelante" (Alfonsín, 1983, p. 4), o: “Mucha gente no sabe qué significa vivir bajo el imperio de la Constitución y la ley, pero ya todos saben qué significa vivir fuera del marco de la Constitución y la ley" (Alfonsín, 1983, p. 4). Enunciados por lo general en primera persona del plural o acompañados

12 Cuando no se brinde otra referencia, el texto entrecomillado y el número de página remiten al dara, en su transcripción disponible en www.ucr.org.ar/public/documentos/alfonsin101283.rtf por cuantificadores, ninguno sintetiza esta confluencia como la percursio ${ }^{13}$ que hilvana la enumeración en el fragmento 2: "con la carga afligente de todos esos males, cuya cuenta precisa y detallada puede ser excusada aquí por ser bien conocida" (Alfonsín, 1983, p. 5). Entre la enumeración y la evidencia, la percursio es la cifra de la tensión que el discurso presidencial de asunción manifiesta entre la ostentación de una situación crítica que se pretende evidente a los ojos de todos los argentinos, y la mitigación de sus agentes responsables, cuyo compromiso resulta disuelto en un clima inmoral de época.

Con estos elementos sobre la mesa, y teniendo en cuenta las características del tópico fundacional, parece pertinente preguntarse cuál ha sido, desde la perspectiva del DARA, la fuente del mal; es decir, quiénes condujeron a los argentinos a esta situación crítica juzgada evidente. Se señala, pues, que una oposición axiológica de índole ética se constituye en eje rector del gesto fundacional, la de la"rectitud de los procedimientos"contra "la inmoralidad pública":

Venimos a exponer a vuestra honorabilidad cuáles son los principales objetivos del gobierno en los diversos terrenos en que debe actuar [...]Pero queremos decir, también, que entre todas las áreas habrá un enlace profundo y fundamental: que una savia común alimentará la vida de cada uno de los actos del gobierno democrático que hoy se inicia: la rectitud de los procedimientos.

13 Por percursio hacemos referencia a "la acumulación enumerativa y coordinante de ideas que podrían merecer ser cada una tratada con detalle (lo que sería la expolición), pero que no recibe dicho tratamiento" (Beristáin, 1995, pp. 31-32). 
Hay muchos problemas que no podrán solucionarse de inmediato, pero hoy ha terminado la inmoralidad pública. Vamos a hacer un gobierno decente.

Ayer pudo existir un país desesperanzado, lúgubre y descreído: hoy convocamos a los argentinos, no solamente en nombre de la legitimidad de origen del gobierno democrático, sino también del sentimiento ético que sostiene a esa legitimidad. (Alfonsín, 1983, p. 1)

Intentemos ahora reconstruir el edificio argumentativo del DARA: el gesto fundacional establece una frontera entre el "autoritarismo" del pasado reciente, "el clima de arbitrariedad, atropello e incertidumbre", y la "democracia" como"marco" de "progreso y bienestar". Esta frontera simbólica cobra también la forma, como ya se dijo, de una división entre "la inmoralidad pública" y la "rectitud de los procedimientos". El énfasis en la condición temporalde la deixis del fragmento tres no hace más que confirmarla: "el gobierno democrático que hoy se inicia”, y también: "Ayer pudo existir un país desesperanzado, lúgubre y descreído: hoy convocamos a los argentinos [...]". El aspecto de las formas verbales contribuye: el presente simple ("se inicia", "convocamos") contrasta con el pasado perfecto ("pudo").

Alfonsín afirma que "El ciudadano común percibirá, de la mañana a la noche, la diferencia entre el autoritarismo y la democracia" (Alfonsín, 1983, p. 10), y apuesta por un "gobierno decente", basado en la "ética" (Alfonsín, 1983, p. 1). Promotor de un corte absoluto, el DARA dispone, por un lado, arbitrariedad, atropello, incertidumbre, inmoralidad, desesperanza, descreimiento; por el otro, progreso, bienestar, rectitud, sentimiento ético. Se trataría de dos atmósferas forjadaspor dos filosofías antitéticas: una "filosofía de la subversión" de raíztotalitaria y una "ética política" de raíz pluralista. Se cita a continuación in extenso un extracto que sintetiza la lógica descrita:

Históricamente nos opusimos a que una pequeña minoría de la población considerada a sí misma como población combatiente, eligiera al gobierno en reemplazo del pueblo. Por eso luchamos para defender el derecho a elegir el gobierno, pero sólo para defender el derecho del pueblo a elegirlo. Esa distinción rechaza desde siempre a la filosofía de la subversión. Pero debe tenerse en cuenta que la Constitución y las leyes son subvertidas, también, por minorías armadas, que reemplazan la ley por las balas, tanto a través del guerrillerismo, como a través del golpismo. Por eso, señalamos categóricamente que combatimos el método violento de las élites, derechistas o izquierdistas.[...]

El método violento de las élites de derecha o de izquierda se justifica a sí mismo con el triunfo definitivo y final, absoluto, de una ideología sobre otra y de una clase sobre otra.

La democracia aspira a la coexistencia de las diversas clases y actores sociales, de las diversas ideologías y de diferentes concepciones de la vida. Es pluralista, lo que presupone la aceptación de un sistema que deja cierto espacio a cada uno de los factores y hace posible así la renovación de los partidos y la transformación progresiva de la sociedad. (Alfonsín, 1983, pp. 3-4) 
Legatario de la democracia por partida doble, como legítimo ganador del sufragio popular y como heredero de la tradición democrática del radicalismo ("Históricamente nos opusimos..."), el locutor opondrá el "derecho del pueblo" a "elegir el gobierno" al "método violento de las élites de derecha o de izquierda", que pretende reemplazar "la ley por las balas, tanto a través del guerrillerismo, como a través del golpismo". Analíticamente, esta crítica de la "filosofía de la subversión" presenta dos estrategias: en primer lugar, la reducción del ethos setentista a una cuestión de élites en pugna por el poder (los términos utilizados no dejan duda al respecto: "pequeña minoría de la población", "minorías armadas", "el método violento de las elites"); en segundo lugar, la subsunción del estatuto de las élites dentro de una misma clase, mediante diferentes procedimientosde equivalencia: conjunciones coordinantes disyuntivas ("derechistas o izquierdistas", "las élites de derecha o de izquierda"), estructuras comparativas ("tanto a través del guerrillerismo, como a través del golpismo") y apelación repetida asufijos del tipo -ismo e -ista, ${ }^{14}$ que ponen de manifiesto una actitud peyorativa del hablante hacia el objeto evocado.

Como conclusión de estas estrategias de reducción y equivalencia, tenemos, entonces, puestos negro sobre blancoviolencia y élites, por un lado, y democracia y pueblo, por otro. Las conclusiones que se derivan de este reparto de las nociones conducen a una mutua implicación de los pares que estaba lejos

14 La utilización de los sufijos -ismo e -ista sugiere la presencia de una subjetividad evaluativa en el dara respecto del ejercicio del poder de las Fuerzas Armadas, así como de la lucha armada de la militancia. Para un análisis detallado de la carga evaluativa de los sufijos, véase Kerbrat-Orecchioni (1986) y, de forma específica, Muñoz Armijo (2010) de ser evidente en el momento de asunción del nuevo presidente. La oposición antitética no solo sostiene el gesto fundacional del DARA sino que constituye como inescindible las relaciones entre democracia y pueblo, y entre violencia y élites. Así, el DARA postula que la violencia expresaa las élites, debido a que el autoritarismo constituiría el único modo posible que tienen de gobernar y de vivir; más importante aún, y decisivo para la perspectiva de una retórica constitutiva, establece que la democracia, como régimen de gobierno y como forma de vida, expresa al pueblo argentino, porque este últimotiene una personalidad ${ }^{15}$ democrática. Este aparejamiento de democracia y pueblo es una novedad fundamental del DARA en la formación política argentina.

Coherente con ello, el DARA realiza dos críticas severasen torno al "autoritarismo" de las élites: una por su concepción de la acción y otra por su concepción del futuro. Se trata de oposiciones parciales que refuerzan, por contraste, las virtudes de una política democrática.La crítica de la acción está relacionada, desde la perspectiva del orador, con la justificación de los medios por los fines:

Quienes piensan que el fin justifica los medios suponen que un futuro maravilloso borrará las culpas provenientes de las claudicaciones éticas y de los crímenes. La justificación de los medios en función de los fines implica admitir

15 Usamos el término "personalidad" debido a las connotaciones krausistas del término en la tradición radical. Como es sabido, la teoría krausista sobre la personalidad moral de las naciones influyó de manera notable sobre Hipólito Yrigoy en y no menos sobre Raúl Alfonsín. Véase, al respecto, Biagini (1989) y Aboy Carlés (2001). Podríamos haber dicho, de manera sinonímica: porque el pueblo argentino es esencialmente o por naturaleza democrático. El sentido es marcar el contraste entre la cultura autoritaria de las élites y la cultura democrática del pueblo. 
la propia corrupción, pero, sobre todo, implica admitir que se puede dañar a otros seres humanos, que se puede someter al hambre a otros seres humanos, que se puede exterminar a otros seres humanos, con la ilusión de que ese precio terrible permitirá algún día vivir mejor a otras generaciones. Toda esa lógica de los pragmáticos cínicos remite siempre a un porvenir lejano. (Alfonsín, 1983, p. 1)

Contra "esa lógica de los pragmáticos cíni$\cos ^{\prime \prime}$, el DARA propone la acción perfectible de la democracia: “La acción, ya sabemos, no llevará a la perfección: la democracia es el único sistema que sabe de sus imperfecciones" (Alfonsín, 1983, p. 2). Este régimen de la acción perfectible se asienta en un punto medio entre los extremos de la perfección inalcanzable, que conduce al "abandono de la ética política” (Alfonsín, 1983, p. 2), y de la inacción, que "sólo puede desarrollarse sobre el fondo de un gigantesco remordimiento" (Alfonsín, 1983, p. 2).

Sugerida por la tensión entre los efectos de la acción humana y la "ilusión" de una sociedad perfecta, debemos mencionar enseguida la cuestión del porvenir, porque el DARA, en su crítica del "autoritarismo", opondrá al "futuro indeterminado" de los "totalitarios" el "futuro tangible" de la democracia:

Nosotros vamos a trabajar para el futuro. La democracia trabaja para el futuro, pero para un futuro tangible. Si se trabaja para un futuro tangible se establece una correlación positiva entre el fin y los medios. Ni se puede gobernar sin memoria, ni se puede gobernar sin la capacidad de prever, pero prever para un tiempo comprensible y no para un futuro indeterminado. Los totalitarios piensan en términos de milenios y eso les sirve para erradicar las esperanzas de vida libre entre los seres humanos concretos y cercanos. (Alfonsín, 1983, p. 1)

No resulta inadecuado afirmar que el gesto fundacional del DARA abre $s u$ tiempo en la distinción de dos tipos de imaginación del futuro: "el futuro tangible" que propone el nuevo Gobierno frente al "porvenir lejano", "el futuro indeterminado" de los "totalitarios". Como corresponde a una instancia enunciativa de ruptura, diferentes formas de regulación de la voz propia y de la del otro negativo recorren el fragmento seis. Al comienzo, la superposición entre gobierno y democracia, mediante el recurso de la repetición, propone un vínculo que le permite al enunciador fundir en un primer plano el presente del nosotros gubernamental con la intemporalidad del componente didáctico (Verón, 1987): “Nosotros vamos a trabajar [...] La democracia trabaja...". Esta aleación de formas habilita al orador a distanciar el componente programático (Verón, 1987) de su promesa de los modos de pensar de los "totalitarios": la promesa de trabajar por un "futuro tangible" difierede los pensamientos "en términos de milenios".

Indicada la conexión gobierno-democracia, procedimientos de restricción polémica por conectores adversartivos ("La democracia trabaja para un futuro, pero...", o bien: "prever, pero prever para..."), abundancia de formas impersonales ("Si se trabaja... se establece...", "Ni se puede... ni se puede...) y presencia reiterada de negaciones (a la doble negación "Ni... ni..." se debe agregar: "no para un futuro indeterminado") componen 
un cuadro en el que la verdad intemporal que postula el enunciador sobre la democracia se entreteje, en el terreno de la pedagogía, con la fuerza polémica de la contradestinación (Verón, 1987): “Los totalitarios piensan en términos de... y eso les sirve para...".

Acción perfectible, futuro tangible, tiempo comprensible: la fuerza política de la democracia es puesta en la perspectiva de una vida; de la misma manera, la vida impregna con su semántica el sentido de la democracia. No sorprende, entonces, que el gesto fundacional resulte codificado en el DARA a través de un cierto naturismo que se articula con tópicos organicistas, higienistas y biologistas. ${ }^{16}$ Salud y enfermedad serán formas de evaluar el estado del país, su vitalidad cívica. Así, por ejemplo, al referir a los falsos diálogos, se va a afirmar que "El país está enfermo de soberbia" (Alfonsín, 1983 , p. 10); si, por el contrario, se trata de una promesa, "sanos principios" aparecen asociados a la verdadera fuerza que estaría en la base del sistema democrático: "vamos a emplear la sensatez, los métodos correctos y los sanos principios. Ellos nos harán fuertes" (Alfonsín, 1983, p. 10). La escisión pasado/futuro parece hecha por el bisturí simbólico de la semántica médica; los ejemplos abundan: si, de cara al futuro, el Estado habría de devenir "dinámico, eficaz y sano" (Alfonsín, 1983, p. 11), es preciso "restañar" las "profundas heridas" de la lucha armada

16 Ya Raiter (1999) había señalado que este tipo de metáforas corporales y médicas resultan funcionales a una exculpación generalizada de los actores. Complementadas con figuras como el paralelismo o la coordinación asociativa, esta estrategia argumentativa presenta a los militares "como las víctimas de una sociedad que no las tuvo bajo su control, y por esta razón, la sociedad como un todo es culpable por las irrupciones de los militares. De todos modos los militares deben también asumir la culpa por haber perdido el sentido de la legalidad, y las irrupciones deben ser deploradas" (p. 118). y el terrorismo de Estado (Alfonsín, 1983, p. 9), así como lograr "la rehabilitación económica del país” (Alfonsín, 1983, p. 16).

La persistencia de tópicos y metáforas que establecen un campo de concomitancia entre las imágenes de un cuerpo enfermo y las de una nación convalenciente encuentran su lugar en el DARA integradas, no obstante, a una tónicanaturista más amplia que establece conexiones entre la fundación democrática y la condición edénica de la naturaleza. Consideremos, por ejemplo, las siguientes expresiones: "arraigo en el tiempo” (Alfonsín, 1983, p. 2), “una savia común alimentará la vida" (Alfonsín, 1983, p. 1), "afirmando sus raíces en las bases y en el interior de la República" (Alfonsín, 1983, p. 15), los "sistemas de fuerza que anidan en la sociedad argentina" (Alfonsín, 1983, p. 8), "profundice el cauce democrático" (Alfonsín, 1983, p. 11), "reverdecerán sus lauros del pasado" (Alfonsín, 1983, p. 43).

Estas metáforas naturistas que tienden a mostrar la democracia como un circuito vitalse oponen al escenario de "un país desesperanzado, lúgubre y descreído" (Alfonsín, 1983, p. 1), que ilustra con sus propios matices góticos la descripción de la situación crítica.A propósito de ello, en Las dos fronteras de la democracia argentina, Gerardo Aboy Carlés (2001) afirma que "El terrorismo de Estado asociado al régimen militar iniciado en 1976 permitió asimilar en el discurso alfonsinista la distancia entre la democracia y la dictadura como una distancia entre la vida y la muerte". Se trata, para el autor, de "el rasgo fundamental que define a la frontera trazada por Alfonsín" (p. 171). 


\section{Hacia una noción ampliada de democracia}

Democracia y vida; la potencia de esta ligadura no debe hacer que perdamos de vista un fenómeno decisivo; esto es, que la vuelta de la democracia asoma en el horizonte de los años ochenta como el tiempo y el espacio políticos para expresar $\mathrm{y}$, sobre todo, satisfacer las demandas sociales de todo tipo postergadas por la reciente dictadura. Cuando triunfa en las elecciones presidenciales de octubre, Alfonsín está en la obligación de liderar un cambio de régimen político, ya que, como afirma Landi, "La democracia no era un sistema funcionando sino una demanda" (1985, p. 30).

En un clima de grandes movilizaciones populares, la democracia como significante condensaba un abanico amplio de reclamos que el DARA hizo suyo para legitimar su lugar de enunciación; de allí que la solución que propone en su fundación de la nueva República incluya al Gobierno del demos como condicióndecisiva de cara al futuro: "Seremos la prueba [de] que renacer es posible..." (Alfonsín, 1983, p. 43), “en la Argentina democrática que hoy volvemos a fundar..." (Alfonsín, 1983, p. 43), o bien: "esta Argentina democrática que da sus primeros pasos" (Alfonsín, 1983, p. 14).

Renacer, dar los primeros pasos; las connotaciones de los términos utilizados deja entrever que la verdaderademocracia constituye para el DARA no solo la promesa de un futuromejor, sino tambiénel resultado de un desarrollo que implica la educación del pueblo soberano. Por eso mismo, el "aprendizaje" del sentido de la democracia por parte del pueblo reviste una importancia mayor. Citamos al respecto un fragmento destacado:

Los pueblos, como los hombres, maduran en el sufrimiento y no seríamos dignos del nombre de pueblo argentino si no fuéramos capaces de aprender la lección del dolor. Lo primero que no debemos olvidar es que lo más valioso que tiene nuestro país son los hombres y las mujeres que lo habitan. No es el petróleo, ni las vacas, ni el trigo, ni las fábricas, sino el trabajo y la capacidad de creación de todos y cada uno de nuestros habitantes lo que da sentido y riqueza a nuestra Argentina, como a cualquier otra nación del mundo.

La segunda lección es que sólo el pueblo se preocupa por el destino del pueblo. Cuando se impide al pueblo decidir su propia suerte, cuando se le prohíbe elegir y controlar al gobierno, tarde o temprano se deja de gobernar para el pueblo. Nadie puede pretender que un gobierno no cometa errores. Pero de una vez por todas haremos que sólo sea el pueblo, por su libre voluntad y dentro de las instituciones democráticas, quien sea el único que juzgue y corrija esos errores. El dolor que vivimos nos ha enseñado que cada vez que se coarta el camino hacia la democracia, la inmensa mayoría de los argentinos termina perjudicándose.

También aprendimos que hay quienes se benefician cuando es la fuerza y no la voluntad libre del pueblo quien impone el gobierno de la Nación. Aprendimos que los que estimulan la impaciencia para proponer la intolerancia y la violencia como remedios, han 
terminado favoreciendo los intereses del privilegio. Aprendimos que cuando el pueblo no decide sobre el gobierno, la Nación y el pueblo quedan desguarnecidos frente a los intereses de adentro y de afuera. (Alfonsín, 1983, p. 48)

Si la democracia es anunciada por el DARA como el régimen de la acción perfectible, resulta lógico entonces que la fundación de una nación democrática traiga aparejada una pedagogía de la democracia. La constitución retórica de un pueblo democrático transita en el DARA entre las "zonas" del saber que componen de suyo la palabra política: ${ }^{17}$ la de la descripción del pasado,cuyo propósito es constatar la evidencia compartida de una situación juzgada crítica a los fines de volverla objeto de "aprendizaje"; y la de la didáctica de principios generales, que dan forma a una enseñanzade la democracia, fundada en una "verdad intemporal".

Este tránsito gnoseológico manifiesta las oscilaciones del DARA entre una posición de relativa igualdad del orador con la audiencia, según la cual este describe un estado de situación como miembro del colectivo de los argentinos ("El dolor que vivimos nos ha enseñado..." (Alfonsín, 1983, p. 48), "Pero los dolores que hemos vivido nos dejaron lecciones que no podemos ni debemos olvidar, lecciones que nos ayudarán[...]" (Alfonsín, 1983, p. 48), “También aprendimos que hay quienes se benefician..." (Alfonsín, 1983, p. 48), "Aprendimos que los que estimulan la impaciencia..." (Alfonsín, 1983, p. 48)), y una posición de franca asimetría, marcada por un "tono didáctico" (Zoppi Fontana, 1997, p. 193), según la cual el orador enuncia principios

17 Véase al respecto Verón (1987) intemporales sobre la democracia: "Los pueblos, como los hombres..." (Alfonsín, 1983, p. 48), "Cuando se impide... se deja..." (Alfonsín, 1983, p. 48), "La segunda lección es que sólo el pueblo se preocupa por el destino del pueblo..." (Alfonsín, 1983, p. 48).

La configuración de una escenografía pedagógica que traduce, en algunos tramos, la instancia institucional de la asunción a una suerte de lección escolar ("la lección del dolor", "La segunda lección es que...") no debería ser menospreciada: diferentes recursos, como la presencia de negaciones metalingüísticas ${ }^{18}$ ("No es el petróleo, ni las vacas... sino el trabajo y la capacidad..."), y el uso de comparaciones ("Los pueblos, como los hombres...", "a nuestra Argentina, como a cualquier otra nación del mundo") permiten ubicar al DARA en el dominio de la competencia (Charaudeau, 2006).

Presentada como solución generala los problemas del país a la salida de la última dictadura militar, la democracia como objeto discursivo exigirá al DARA una voluntad educativa que transforme la legitimidad política del régimen en una forma legítima de sociedad, en un contexto donde, de acuerdo con Smulovitz (citado en Gargare1la, Murillo y Pecheny, 2010), ni los actores ni los factores que hasta entonces habían dificultado la estabilización de un régimen democrático resultaban superados o siquiera neutralizados. ¿Qué significa una real democracia?, ¿para qué sirve?, ¿cómo podemos vivir en democracia? Las respuestas

18 Según García Negroni (1998), la negación metalingüística, que opone dos locutores diferentes o un mismo locutor en momentos diferentes, siempre es descalificadora de un marco de discurso previo y tiene la función fundamental de instaurar un nuevo espacio de discurso, presentado por el locutor como el único adecuado para la caracterización argumentativa de la situación de la que habla. 
a estas preguntas le presentarán al alfonsinismo el desafío de reformular el sentido de la democracia, de ampliar sus implicancias; sobre todo,de volverlo capaz de cobijar en su interior no solo a quienes exigían de la democracia un ámbito creciente de libertad y pluralidad, sino también a quienes exigían justicia social y mejoras en las condiciones generales de existencia.

Esta pedagogía de la democracia envuelve, en primer lugar, un elogiode la democracia, cuya figura se recorta sobre el fondo del "régimen": "La democracia será desde el primer momento, una fuerza movilizadora. La democracia moviliza siempre, mientras que el régimen desmoviliza" (Alfonsín, 1983, p. 2). Esta alabanza involucra los diferentes planos del Gobierno del demos: en el plano procedimental, la democracia, por medio del sufragio, "implica la posibilidad de que gobierne el pueblo y de que el Estado sea independiente" (Alfonsín, 1983, p. 3); también "garantiza la inserción de la Argentina en el mundo como nación independiente" (Alfonsín, 1983, p. 3); mientras que en el plano sociocultural, la democracia es "pluralista" (Alfonsín, 1983, p. 4), “dinámica, plena de participación y movilización popular" (Alfonsín, 1983, p. 5), "previsible" (Alfonsín, 1983, p. 7), "sabe de sus imperfecciones" (Alfonsín, 1983, p. 2).

De forma paralela a las alabanzas, el DARA lleva a cabo, en segundo lugar, una verdadera reformulación del concepto de democracia, y expande asísu significado para conjugar en ella todo tipo de derechos civiles y sociales. A continuación se presenta la secuencia argumentativa más relevante a la hora de analizar esta operación:
Vamos a establecer definitivamente en la Argentina la democracia que todos los argentinos queremos, dinámica, plena de participación y movilización popular para los grandes objetivos nacionales, en el marco bien definido pero históricamente flexible de nuestra Constitución, que garantiza todos los derechos, todas las libertades, todos los avances sociales y culturales del mundo moderno, a la vez que asegura la responsabilidad de los gobernantes ante el pueblo a través de los mecanismos jurídicos y políticos de control que la misma Constitución ha previsto, y de la periódica renovación de los poderes mediante el ejercicio del sufragio.

Vamos a vivir en libertad. De eso, no quepa duda. Como tampoco debe caber duda de que esa libertad va a servir para construir, para crear, para producir, para trabajar, para reclamar justicia -toda la justicia, la de las leyes comunes y la de las leyes sociales-, para sostener ideas, para organizarse en defensa de los intereses y los derechos legítimos del pueblo todo y de cada sector en particular. En suma, para vivir mejor; porque, como dijimos muchas veces desde la tribuna política, los argentinos hemos aprendido, a la luz de las trágicas experiencias de los años recientes, que la democracia es un valor aún más alto que el de una mera forma de legitimidad del poder, porque con la democracia no sólo se vota, sino que también se come, se educa y se cura. (Alfonsín, 1983, p. 5)

La secuencia argumentativa comienza por ofrecer una definición programática de la 
democracia en la tradición del radicalismo: la tríada libertad/república/modernización enmarca el significado del "gobierno del pueblo" en el ámbito de la "Constitución", "la periódica renovación de los poderes mediante el ejercicio del sufragio" y la garantía de "todos los derechos, todas las libertades, todos los avances sociales y culturales del mundo moderno". Estamos en el plano de la democracia como régimen $\mathrm{o}$, para decirlo con las palabras de Alfonsín, de "una mera forma de legitimidad del poder".

Ahora bien, esta secuencia tiene por corolario la primera frase del segundo párrafo: "Vamos a vivir en libertad". La promesa, sin embargo, adquiere consistencia en la definición de la libertad no solo como ejercicio de los derechos civiles (e. g. "reclamar justicia" o "sostener ideas"), sino también como condición de posibilidad del ejercicio de derechos sociales: desde "trabajar" y "producir" hasta “organizarse en defensa de los intereses". La enumeración de todas las posibilidades que abre la libertad, cuyos efectos son hilvanados por el recurso de la anáfora ("para construir, para crear, para producir..."), culmina con una congéries que da pie a la reformulación: "En suma, para vivir mejor".

La argumentación nos conduce de la democracia como un sistema para "vivir en libertad" a uno para "vivir mejor". La distancia entre los sintagmas se explica a través de la reformulación no parafrástica amplificadora $^{19}$ que se ha vuelto, a la postre, un

19 En la bibliografía especializada, se afirma que proponer una reformulación implica, por parte del locutor, un comportamiento cooperativo motivado por el afán o la ambición de evitar equívocos posibles y de superar obstáculos comunicacionales. García Negroni (2009) señala que la reformulación constituye "una operación reflexiva en que la referencia se hace sobre un enunciado emitido anteriormente" (Calsamiglia y Tusón, 2002, p. 310) y que muestra por parte del locutor, que retoma algún elemento anterior para presentarlo de otro modo lema de la transición democrática: “con la democracia no sólo se vota, sino que también se come, se educa y se cura".

Sufragio, alimento, educación, salud; punto de convergencia política y social, la democracia opera como un significante elástico que le permite al DARA realizar un cambio de perspectiva enunciativa, apostando a reconciliar, como ha sido sugerido Torre (1990), los dos campos antitéticos demarcados por el triunfo de Perón en los comicios del 24 de febrero de 1946: el de la aspiración a una sociedad más justa, en términos de distribución del ingreso nacional, y el de los defensores de la democracia política, democracia que podía muy bien ser indolente ante profundas diferencias sociales.

La recapitulación de las virtudes de la democracia, introducida por el marcador recapitulativo "en suma”, amplifica el sentido de la noción, albergando bajo su paraguas las demandas de libertad (pluralidad, diversidad, "sostener ideas") y las de justicia social (trabajo, abrigo, alimentación, educación, salud). Radicalismo y peronismo: la consolidación de la democracia estaba subordinada para el DARA, en este sentido, a la "conciencia de la unión nacional": "Sin la conciencia de la unión nacional será imposible la consolidación de la democracia" (Alfonsín, 1983, p. 8).

\section{Performación ética de la democraciay de la ciudadanía}

Con diferentes significados de acuerdo con la orientación ideológica de los sectores sociales, el DARA apostó a enmarcar el

o para puntualizar su significado, su voluntad de ejercer un cierto control metadiscursivo de la producción del sentido (véase García Negroni, 2009). 
pluralismo inherente a su programa democrático con los límites de la ética. La fuerza de la democracia como significante constitutivo de la nueva Repúblicaradicaría, desde esta óptica, en el sustrato ético que la alimenta, en las antípodas del "método violento de las élites de derecha o de izquierda". La éticacomo "núcleo de la política hacía previsible — según Landi- la acción del otro y por lo tanto posible el logro de los objetivos", en "un país descreído de la política y con desconfianzas mutuas profundas" (1985, p. 41).

Esta condición ética es, por un lado, la que va a sostener la legitimidad del Gobierno democrático: "hoy convocamos a los argentinos, no solamente en nombre de la legitimidad de origen del gobierno democrático, sino también del sentimiento ético que sostiene esa legitimidad" (Alfonsín, 1983, p. 2). Por el otro, la que va a justificar como realizable la reiterada promesa de unión en diversidad. La apelación a la ética conducirá a una reinterpretación de la unión nacional: “Aún el objetivo de construir la unión nacional debe ser cabalmente interpretado a través de la ética" (Alfonsín, 1983, p. 2).

No hablamos de una sanción de la ideología en provecho de la ética, sino de un argumento de jerarquía: la ética está por encima de las ideologías y debe orientar sus consecuencias prácticas. Tal es así que el "sentimiento ético" y el "pluralismo ideológico" (Alfonsín, 1983, p. 36) comparten en su mutua dependencia un rechazo de la violencia y del mesianismo ideológico, representado por el "triunfo definitivo y final, absoluto, de una ideología sobre otra y de una clase sobre otra":
El método violento de las élites de derecha o de izquierda se justifica a sí mismo con el triunfo definitivo y final, absoluto, de una ideología sobre otra y de una clase sobre otra.

La democracia aspira a la coexistencia de las diversas clases y actores sociales, de las diversas ideologías y de diferentes concepciones de la vida. Es pluralista, lo que presupone la aceptación de un sistema que deja cierto espacio a cada uno de los factores y hace posible así la renovación de los partidos y la transformación progresiva de la sociedad. (Alfonsín, 1983, p. 3)

Cuando Alfonsín afirma que "Seremos más que una ideología, una ética" (Alfonsín, 1983, p. 4) significa la posibilidad de unir a través de la ética a un auditorio dividido ideológicamente, o para decirlo en los términos de una retórica constitutiva: el DARA busca convertir a un auditorio dividido por las ideologías en un auditorio unido por la ética, y la garantía de esa conversión ética es la doble faz de la democracia como sistema de gobierno y como forma de sociedad "pluralista".

Unidad y pluralidad. Esta díada resume la tensión constitutiva del DARA: por un lado, construir un consenso democrático que conduzca a la "unión nacional" en las ascuas de uno de los periodos más violentos de la historia argentina; por el otro, apostar a un "pluralismo democrático" en el que la unión del conjunto no aplaste la anunciada condición polifónica de la democracia. Con la legitimidad de una performance electoral histórica, el alfonsinismo se propuso articular "un espacio de recepción múltiple" a partir de "elementos capaces de suscitar 
adhesión inmediata por parte de cualquier sector" (Arfuch, 1987, pp. 37-38). La primacía de la ética sobre la ideología constituyó, al respecto, un factor decisivo, ya que fue la punta de lanza de una convocatoria que se manifestaba prescindente de las ideologías, fomentando, al mismo tiempo, el pluralismo ideológico, por oposición a la "uniformidad ideológica" (Alfonsín, 1983, p. 13) del pasado. Bajo la disposición de una estrategia argumentativa jerárquica, la noción de democracia conjuga en el DARA el respeto de las ideologías y su subordinación a un "sentimiento ético" que las trasciende. ${ }^{20}$

Regida por una experiencia vital de la ética, la democracia se vuelve apta, según la visión del DARA, para albergar "diversas clases y actores sociales", "diversas ideologías" y "diferentes concepciones de la vida". Este pluralismo de base ética encuentra su razón de ser en una "política de principios", cuya sustancia universal e intemporal debe ser aprehendida en la interacción pedagógica entre Gobierno y pueblo. El aprendizaje democráctico exige así una retórica del conjunto que, frente a las "dificultades" "múltiples e inmensas" de la nación, apueste al empeño colectivo o "voluntad del conjunto" (Alfonsín, 1983, p. 43). Son ejemplos: "Vamos a establecer definitivamente en la Argentina la democracia que todos los argentinos queremos" (Alfonsín, 1983, p. 5), o bien: "en este empeño [el de salir adelante] estamos todos unidos" (Alfonsín, 1983,

20 Esta prescindencia respecto al debate ideológico fue una de las características que Arfuch destacó al trabajar el discurso de Alfonsín en la campaña electoral presidencial: "Al desplazar a un segundo plano la afirmación de la identidad partidaria para presentarse como instancia unificadora, el discurso alfonsinista se colocaba también en una posición prescindente respecto del debate ideológico [...]" (1987, p. 37). p. 4). En el marco del "nuevo comienzo", la empresa colectiva se impone:

La noción de ser protagonistas de este nuevo comienzo, que será definitivo, nos inspira a todos un sentimiento de responsabilidad acorde con el esfuerzo que hoy emprendemos juntos, y nos infunde el valor para afrontar un conjunto de dificultades muy graves que acosan a nuestra patria. (Alfonsín, 1983, p. 4)

Unión nacional: las últimas palabras de Alfonsín son "Con el esfuerzo de todos, en unión y libertad, que así sea". Retoma, de esta manera, el lema "En Unión y en Libertad", que estaba inscrito en el anverso de las primeras monedas patrias, acuñadas en 1813 luego de la revolución de mayo de 1810, que inició la independencia argentina de España. Si la presencia interdiscursiva del lema patrio enfatiza el gesto fundacional del DARA, también destaca que el "nuevo comienzo" es una responsabilidad del conjunto de los argentinos.

Partículas de conjunto atraviesan la secuencia argumentativa, volviendo palmario el intento alfonsinista de fundar su legitimidad ante un amplio espectro social y sectorial, en el marco de un imaginario político de convocatoria inclusiva (a partir, por ejemplo, del colectivo: "nosotros, los argentinos"): "todos los argentinos", "juntos", "unidos", "voluntad de conjunto", "espíritu de unidad nacional". Esta retórica omniabarcativa no excluyeni la mención de la oposición política, que recibe elogios, ni vaticinios de un "estilo republicano" marcado por "tempestuosos debates y agrios enfrentamientos de coyuntura": 
Estamos cargados de ideales y de sueños que vamos a realizar en forma honesta y razonable. Contamos con la amplia y comprensiva disposición al diálogo de la oposición, que está demostrando desde ahora la generosidad y patriotismo con que, a través de la crítica, colaborará en la consolidación del proyecto democrático. Ese espíritu de unidad nacional que hace vibrar a todo el país no excluirá, sin duda, tempestuosos debates y agrios enfrentamientos de coyuntura que nutrirán al estilo republicano triunfante ya en el país. (Alfonsín, 1983, p. 7)

Sucede que para el DARA, como dijimos, la democracia conjuga unidad y pluralidad. Zoppi Fontana lo explica de esta manera en relación con la discursividad de Alfonsín: "Nuestros análisis sobre las formas de representación del sujeto nos permitieron observar este deslizamiento a través de la alternancia[...] entre la forma del todos colectivo y la forma del cada uno universal" (1997, pp. 191-192). El funcionamiento de estas formas manifiesta para la autora "definiciones contradictorias del ciudadano y de la práctica política":

Por un lado, una noción de ciudadanía, en la cual los individuos se enfrentan como sujetos comprometidos con un hacer político, interviniendo activamente en la sociedad. Por otro lado, una noción de ciudadanía, en la cual los individuos son interpretados como elementos singulares e intercambiables de una misma clase conceptual. (Zoppi Fontana, 1997, pp. 191-192)

Resulta consistente, entonces, que el pueblo argentino sea construido por el DARA con el derecho a elegir a sus gobernantes, como ciudadano, con expresiones del tipo"el derecho del pueblo a elegir" (Alfonsín, 1983, p. 49), "los ciudadanos" (Alfonsín, 1983, pp. 5, 6, 7, 8, 9, 35), "el gobierno del pueblo" (Alfonsín, 1983, p. 48), "la libre voluntad del pueblo" (Alfonsín, 1983, p. 47), “en pleno ejercicio de sus responsabilidades" (Alfonsín, 1983, p. 13), entre otras. Pero si el pueblo en cuanto ciudadano y sujeto de derecho tiene unidad, en cuanto sujeto de opinión es sede de la diversidad, de allí que Alfonsín se refiera a "la natural pluralidad de la república democrática" (Alfonsín, 1983, p. 9 ) o a "la natural diversidad de opiniones de los ciudadanos, sin cesuras ideológicas y sin discriminaciones" (Alfonsín, 1983, p. 9), o utilice sintagmas como "la diversidad" (Alfonsín, 1983, p. 10) o "el pluralismo ideológico" (Alfonsín, 1983, p. 36).

La dialéctica constitutiva de la identificación/división que plantea Anderson atraviesa el dispositivo enunciativo del DARA. En su discurso aparece el nosotros exclusivo con referencia a "nosotros, los de mi gobierno" y el nosotros inclusivo con la referencia a "nosotros, los argentinos", que constituye el lazo de identificación entre el orador y la audiencia. La casi nula aparición de la primera persona del singular, que es reemplazada por la primera persona plural, a veces para referirse a los argentinos en su conjunto y otras para referirse a quienes lo acompañan en su gobierno, más el uso de partículas reforzadoras de conjunto, establece un terreno de mutua permeabilidad entre las esferas del Gobierno y del pueblo y mitiga los efectos de asimetría que produce la posición misma del líder político: ${ }^{21}$

21 En Ciudadanos modernos, Zoppi Fontana ha destacado, respecto del liderazgo de Alfonsín, "la doble visibilidad del porta-voz", que 
Arfuch señala con precisión la tendencia de la discursividad alfonsinista a buscar "un 'efecto de proximidad'” (1987, p. 49).

Funcional a este efecto, el pluralismo, condición sine qua non de la democracia para el DARA, significa en los hechos una apuesta por el "diálogo", cuya génesis reposa en el postulado de las verdades relativas o parciales. De esta manera, Alfonsín disocia la noción de diálogo en real y en aparente sosteniendo: "El diálogo, para ser efectivo, será un diálogo real que presupondrá el reconocimiento de que no tenemos toda la verdad" (Alfonsín, 1983, p. 7). Y, con el mismo posicionamiento que subyace a la Nueva Retórica de Chaïm Perelman (1989) cuando postula que una de las condiciones de la argumentación es estar dispuesto a dejarse persuadir por el otro y cambiar de opinión, Alfonsín agrega: “¿Para qué escucharíamos si no estuviésemos dispuestos a rectificar conductas?" (Alfonsín, 1983, p. 7). El diálogo propuesto también se ejercita en la interrogación retórica: “¿Para qué escucharíamos si no estuviéramos dispuestos a rectificar conductas? ¿Para qué rectificaríamos conductas si no pensáramos que ellas pueden ser equivocadas en algunos casos?" (Alfonsín, 1983, p. 7). Al mismo tiempo, la promoción del diálogo participa en el DARA de una pedagogía del diálogo, basada, como ya señaló, en la verdad intemporal del componente didáctico: "El diálogo no es nunca la sumatoria de diversos monólogos sino que presupone una actitud creadora e

resulta a la vez "actor participante en el acontecimiento discursivo como par o igual de los demás actores sociales que representaba" y "'mirada reflexiva'" que "se diferencia del resto del grupo por su capacidad de producir [...] un cierto tipo de conocimiento sobre el acontecimiento discursivo" (1997, pp. 190-191). imaginativa por parte de cada uno de los interlocutores" (Alfonsín, 1983, p. 8).

\section{Conclusiones}

En el epílogo de su extenso discurso inaugural, Alfonsín apeló al recurso de la preterición para excusarse de "palabras sobreabundantes", debido a la evidencia de una "emoción cívica" "compartida y unánime" (Alfonsín, 1983, p. 47). A continuación, afirmaría que "La circunstancia no es propicia para la retórica", ya que es "la hora de la acción y de la acción fecunda, decidida, comprometida e inmediata. Es la hora de hacer, de hacer bien, de hacer lo que la República reclama y el pueblo espera" (Alfonsín, 1983, p. 47).

Con distancia ante la sedimentada oposición decir-hacer y desde la guía general de los postulados de la retórica constitutiva, hemos intentado demostrar, pese al énfasis en contrario del orador Alfonsín, que la circunstancia estuvo atravesada de principio a fin por el poder retórico de la palabra. Como explican Karlyn Campbell y Kathleen Jamieson (2008), los discursos de asunción tienen como prioridad la constitución retórica del "pueblo", unificando a la audiencia, dividida por la campaña electoral, convención a la que se adecua la alocución de asunción de Alfonsín.

Nuestro análisis permite demostrar que el DARA apostó a constituir al pueblo argentino como pueblo democrático,a partir de diferentes procedimientos retóricos: la apelación a un tópico fundacional, marcado por una oposición axiológica de naturaleza ética que performó la unidad del pueblo por sobre las diferencias ideológicas; la configuración de un dispositivo enunciativo pedagógico que 
incluye, de manera destacada, la reformulación ampliada del significado mismo de la democracia, conjugando demandas de variado calibre.

Cualesquiera que sean las consideraciones sobre el devenir histórico de la democracia instaurada desde 1983 en Argentina, una cosa es segura: aunque los políticos se encarguen de aclarar que las circunstancias no son propicias para la retórica o que sus palabras carecen de ella, la democracia y la política son construidas, en las luchas sociohistóricas por la hegemonía, por la fuerza del discurso, es decir, por la retórica.

\section{REFERENCIAS}

Aboy Carlés, G. (2001). Las dos fronteras de la democracia argentina: la reformulación de las identidades politicas de Alfonsín a Menem. Rosario: Homo Sapiens.

Alfonsín, R. (1983). Mensaje presidencial a la Honorable Asamblea Legislativa. Buenos Aires: Imprenta del Congreso de la Nación.

Anderson, D. (2007). Identity's Strategy: Rhetorical Selves in Conversion. Columbia: University of South Carolina Press.

Arfuch, L. (1987). Dos variantes del juego de la política en el discurso electoral de 1983. En E. Verón et al. (Eds.) El discurso político. Lenguajes y acontecimientos (pp. 27-52). Buenos Aires: Hachette.

Austin, J. L (2003). Cómo hacer cosas con palabras. Buenos Aires: Paidós.

Aznar, L.etal. (1986). Alfonsin: discursos sobre el discurso. Buenos Aires: Eudeba.

Barros, S. (2002). Orden, democracia y estabilidad. Discurso y política en la Argentina entre 1976 y 1991. Córdoba: Alción.
Beristáin, H. (1995). Diccionario de retórica y poética. México, D. F.: Porrúa.

Biagini, H. (Comp.) (1989).Orígenes de la democracia argentina. El trasfondo krausista. Buenos Aires: Legasa.

Bruner, M. L. (2002). Strategies of Remembrance.Therhetoricaldimensions of National Identity. Universityof South Carolina Press.

Burke, K. (1969). A rhetoric of motives. Berkeley and Los Angeles: University of California Press.

Campbell, K. y Jamieson, K. H. (2008). Presidents Creating the Presidency.Deeds Done in Words. Chicago: The University of Chicago Press.

Cassin, B. (2008). El efecto sofístico. México, D. F.: Fondo de Cultura Económico.

Cavarozzi, M. (1997). Autoritarismo y democracia, 1955-1996. La transición del Estado al mercado en la Argentina. Buenos Aires: Ariel.

Charaudeau, P. (2006). Discurso político. São Paulo: Contexto.

Charaudeau, P. (2009). Reflexiones para el análisis del discurso populista. Discurso $\mathcal{E}$ Sociedad, 3(2), 253-279.

Charland, M. (1986). Constitutive Rhetoric. Quarterly Journal of Speech, 73(2), 133-150.

De Riz, L. (1989). La Argentina de Alfonsín: la renovación de los partidos y el Parlamento. Buenos Aires: Centro de Estudios de Estado y Sociedad [CEDEs].

Delamata, G. (1997). Populismos y derechos: aspectos simbólicos en la formación de la ciudadanía en Argentina antes y después de Alfonsín. Madrid: Universidad Complutense.

Epstein, E. (1992). The new Argentine democracy: the search for a successful formula. Westport: Praeger. 
García Negroni, M. M. (1988). La destinación en el discurso político: una categoría múltiple, Lenguaje en contexto, 1(1/2), 85-111.

García Negroni, M. M. (1998). La negación metalingüística: argumentación, gradualidad y reinterpretación. Signo y Seña, 9, 227-252.

García Negroni, M. M. (2009). Reformulación parafrástica y no parafrástica y ethos discursivo en la escritura académica en español. Letras de hoje, 44(1), 46-56.

García Negroni, M. M. y M. Tordesillas (2001). La enunciación en la lengua. De la deixis a la polifonía. Madrid: Gredos.

Gargarella, R., Murillo, M. V. y Pecheny, M. (Comps.) (2010): Discutir Alfonsín. Buenos Aires: Siglo xxI.

Hilb, C. (1990).Promesa y política. Promesas traicionadas y transición democrática. Buenos Aires: Instituto de Investigaciones "Gino Germani"-Universidad de Buenos Aires [IIGG-UbA]. Mimeo.

Kerbrat-Orecchioni, C. (1986). La enunciación. De la subjetividad en el lenguaje. Buenos Aires: Edicial.

Kraus, M. (2012). The Making of Truth in Debate: The Case of (and a Case for) the Early Sophists. En Ch. Kock y L. Villadsen (Eds.), Rhetorial Citizenship and Public Deliberation (pp. 28-45).Pennsylvania: State University Press.

Kraus, M. (2014). Cultural diversity, globalization, and political correctness: Rhetorical argumentation in multicultural societies. En H. Van Belle et al. (Eds.), Let's talk politics. New essays on deliberative rhetoric (pp. 45-59). Amsterdam: John Benjamins Publishing Company.

Landi, O. (1985). El discurso sobre lo posible. (La democracia y el realismo político).
Buenos Aires: Centro de Estudios de Estado y Sociedad [CEDEs].

Lavandera, B. (1985). Decir y aludir. Una propuesta metodológica. Revista de Filología XX (2), 21-31.

Lavandera, B. (Dir.) (1986). Análisis sociolingüístico del Discurso Político 1.Cuadernos del Instituto de Lingüística. Buenos Aires: Instituto de Lingüística.

Lavandera, B. (Dir.) (1987). Análisis sociolingüístico del Discurso Político 2.Cuadernos del Instituto de Lingüística. Buenos Aires: Instituto de Lingüística.

López Eire, A. (2002). Poéticas y Retóricas griegas. Madrid: Síntesis.

López Eire, A. (2005a). Sobre el carácter retórico del lenguje y de cómo los antiguos griegos lo descubrieron. México, D. F.: Universidad Nacional Autónoma de México [unAm].

López Eire, A. (2005b). La naturaleza retórica del lenguaje. Logo. Revista de Retórica y teoría de la comunicación, 8/9, 5-254.

Menéndez, S. y Raiter, A. (1986). El desplazamiento de un signo ideológico. Filología XX, 2, 147-174.

Muñoz Armijo, L. (2010). La historia de los derivados en -ismo e -ista en el español moderno. Barcelona: Universidad Autónoma de Barcelona.

Novaro, M. (2006). Historia de la Argentina contemporánea: de Perón a Kirchner. Buenos Aires: Edhasa.

Novaro, M. (2010). Historia de la Argentina: 1955-2010. Buenos Aires: Siglo xxI.

Novaro, M. y V. Palermo (2003) Historia argentina. La dictadura militar 1976/1983. Del golpe de Estado a la restauración democrática. Buenos Aires: Paidós.

Nun, J. y Portantiero, J. C. (Comps.) (1987). Ensayos sobre la transición democrática en la Argentina. Buenos Aires: Puntosur. 
Perelman, Ch. y Olbrechts-Tyteca, L. (1989). La Nueva Retórica. Tratado de la argumentación. Madrid: Gredos.

Pernot, L. (2002). La retórica en Grecia y Roma. México, D. F.: Universidad Nacional Autónoma de México [unAm].

Podetti, M., Qués, M. E. y Sagol, C. (1992). Política, medios y discurso en la Argentina. Buenos Aires: Centro Editor de América Latina [CEAL].

Pucciarelli, A. (Coord.) (2006). Los años de Alfonsín. ¿El poder de la democracia o la democracia del poder? Buenos Aires: Siglo xxI.

Raiter, A. (1987). Diálogo discursivo e iniciativa discursiva. En B. Lavandera (Ed.), Cuadernos del Instituto de Lingüística. Análisis sociolingüístico del discurso político II. Buenos Aires: Instituto de Lingüística.

Raiter, A. (1999). Transformaciones discursivas en el discurso político. En Lingüística y política. (pp. 95-121). Buenos Aires: Biblios.

Rock, D. (1991). Argentina 1516-1987. Desde la colonización española hasta Raúl Alfonsín. Buenos Aires: Alianza.

Schvarzer, J. (1998). Implantación de un modelo económico. La experiencia argentina entre 1975 y el 2000. Buenos Aires: A-Z editora.
Torre, J. C. (1990). La vieja guardia sindical y Perón: sobre los orígenes del peronismo. Buenos Aires: Sudamericana.

Van Belle, H. et al. (2014). Let's talk politics. New essays on deliberative rhetoric. Amsterdam: John Benjamins Publishing Company.

Verón, E. (1987). La palabra adversativa. Observaciones sobre la enunciación política. En Verón et al. (Eds.). El discurso político. Lenguajes y acontecimientos (pp. 11-26). Buenos Aires: Hachette.

Velázquez Ramírez, A. (2015). De la concertación a la Multipartidaria: el espacio político partidario en los albores de la transición a la democracia en Argentina (1980-1981). Revista contemporânea, 1, 1-28 White, J. B. (1985). Heracles' Bow. Madison: University of Wisconsin.

Zoppi Fontana, M. (1993). Sonhando a Pátria: Os fundamentos de repetidas fundações. Em E. Orlandi (Org.), Discurso fundador (pp. 127-149). Campinas: Pontes.

Zoppi Fontana, M. (1995). Processos de nomeação e interpelação política. $\mathrm{O}$ nós do discurso alfonsinista. Cadernos do Instituto de Letras - UFRGS, 13, 95-104.

Zoppi Fontana, M. (1997). Ciudadaõs Modernos. Discurso é representação política. Campinas: Editora da Unicamp. 